\title{
Scientific Reasoning Competencies: a Case of Preservice Teacher Education
}

\author{
Samia Khan (D) - Moritz Krell
}

Published online: 19 November 2019

(C) The Author(s) 2019

\begin{abstract}
In this study, we analysed the scientific reasoning competencies of preservice science teachers from a Canadian sample at the beginning and end of a science teacher education methods course. The course contained standard topics, such as the nature of science, assessment, and unit and lesson planning in science. The preservice science teachers were asked to reason about two types of problems in a validated pre- and post-questionnaire: investigatory-process problems and problems regarding modeling. Statistical analysis of the data revealed that the course significantly contributed to the development of preservice science teachers' competencies for those who had two previous degrees compared with those that did not. Furthermore, a greater proportion of teachers were deemed highly competent at planning investigations and testing models than the more generative dimensions of scientific reasoning, such as formulating questions and generating hypotheses. Implications for science teacher education internationally and the movement towards competency-based curricula are put forward.
\end{abstract}

Résumé Dans cette étude, nous avons analysé les compétences en matière de raisonnement scientifique chez les futurs enseignants de sciences provenant d'un échantillon canadien, au début et à la fin d'un cours sur les méthodes d'enseignement des sciences destiné aux enseignants en formation. Le cours traitait de sujets attendus tels que la nature des sciences, l'évaluation ainsi que la planification d'unités pédagogiques et de leçons. Au moyen de questionnaires pré-participation et post-participation validés, on a demandé aux futurs enseignants de sciences de raisonner sur deux types de problèmes : les problèmes de processus d'investigation et les problèmes de modélisation. L'analyse statistique des données révèle que le cours a contribué de manière significative au perfectionnement des compétences des enseignants de sciences en formation qui avaient déjà deux diplômes antérieurs comparativement aux autres. En outre, un plus grand nombre d'enseignants ont été jugés hautement compétents pour élaborer des enquêtes et tester des modèles plutôt que pour les aspects plus génératifs du raisonnement scientifique, par exemple formuler des questions

S. Khan

School of Education and Social Work, University of Dundee, Dundee, UK

S. Khan $(\bowtie)$

Department of Curriculum and Pedagogy, University of British Columbia, Vancouver, Canada

e-mail: Samia.khanubc@gmail.com

M. Krell

Institut für Biologie, Freie Universität Berlin, Berlin, Germany 
et générer des hypothèses. Certaines implications pour la formation des enseignants de sciences au niveau international, et pour le mouvement en faveur de programmes d'enseignement basés sur les compétences, sont ensuite avancées.

Keywords Science education · Preservice teacher education · Scientific reasoning · Curriculum · Competency

\section{Research Aims}

It is assumed that the ability to reason well in science enables some participation in those complex issues facing society and involving science, such as climate change (e.g. Hodson, 2014; Ford, 2008). Especially in "post-truth times", where personal beliefs appear to be highly influential in shaping people's opinions, an understanding of science and its procedures, capabilities, and limitations has become increasingly important (Lubchenco, 2017). In addition to scientific reasoning, these issues require an understanding of sociocultural contexts of science, public policy, and individual decision-making (Kelly et al., 1993). Osborne (2013) further suggests that economic needs appear to be another driving force for the integration of scientific reasoning competencies in science education curricula and documents. Scientific reasoning competencies are seen, for example, in the PISA studies, as an indicator for the societies' future economic competitiveness (cf. OECD, 2010). Being competent at reasoning scientifically is often considered globally as one outcome of a good science education (e.g. Hodson, 2011; KMK, 2005; NGSS Lead States, 2013).

In this study, researchers investigated whether secondary preservice science teachers' ability to reason in science changes in teacher education. Science teacher education commonly focuses on how to teach particular topics in science. With the increasing emphasis on the practices and the nature of science, the researchers wished to learn whether preservice science teachers also are becoming more competent at several aspects of scientific reasoning. Two research questions guided this study: first, to what extent do secondary preservice science teachers possess scientific reasoning competencies; second, to what extent does a secondary science teacher education methods course influence secondary preservice science teachers' scientific reasoning competencies?

Prior longitudinal research has shown that over the years, future teachers in university tend to become more competent in their ability to reason in science (Hartmann et al., 2015); however, this study attempts to investigate these findings in the context of an intensive science teacher education course and further hypothesises the possible role of a science teacher program in fostering scientific reasoning competencies.

To investigate the two aforementioned questions, a cohort of Canadian secondary preservice science teachers were assessed with multiple-choice problems in science before and after their science teacher education methods course. The preservice teacher assessment involved a validated multiple-choice questionnaire (Krell et al., 2018; Hartmann et al., 2015). British Columbia (BC) was considered an internationally relevant case study for research on competencies and the role of science teacher education in the development of competencies because (1) a new competency-focused curriculum was introduced in 2018 that is now mandated for teachers; and (2) some universities in BC offer an intensive after-degree teacher education program, where future secondary science teachers engage in concepts related to science teaching formally in a single semester. This type of program also differs from a concurrent program where exposure to teacher education concepts occurs over the duration of a longer 3- to 5-year degree period, focusing the present study on a delineated period where preservice teachers engage with science methods in their first semester in the program. Given the wider curricular emphases on complex problem solving in science and developing "thinking" competencies among students (cf. Quebec Education Program, 2001; Alberta Program of Studies, 2016; BC Curriculum, 2019), this study aims to suggest several recommendations on how science teacher education more globally can support future science teachers in this area. 


\section{Theoretical Background on Scientific Reasoning Competencies}

\section{Competencies}

Competencies can be defined broadly as, "Context-specific cognitive dispositions that are acquired by learning and needed to successfully cope with certain situations or tasks in specific domains" (Klieme et al., 2008 , p. 9). In science curricula, the term skills has often been employed pertaining to scientific inquiry skills (e.g. Nehring et al., 2015); however, Weinert (2001) acknowledges that, "the boundary between skill and competencies is fuzzy" (p. 62). He attempts to distinguish between competencies and skills by proposing to use the term competencies to describe dispositions needed to become good at tasks with a sufficient degree of complexity, whereas the term skills, he suggests, relates to less complex dispositions, such as critical thinking skills. Hence, competencies are, "[I]nterpreted as a roughly specialized system of individual skills that are necessary or sufficient to reach a specific goal" (Weinert, 2001, p. 45).

Some of the scholarly discussion about the term competencies includes to what extent competencies should be understood as purely cognitive or including motivational and affective components. While Klieme et al. (2008) prefer a parsimonious approach to competencies as purely cognitive dispositions for assessment purposes, other researchers propose to understand competencies more holistically as, "[C]omprised of cognitive and (in many cases) motivational, ethical, volitional, and/ or social components" (Weinert, 2001, p. 62). Notwithstanding the inclusion of motivational, volitional, and social components in a definition of competencies, the core concept of competencies as a disposition and complex system (of skills) has some salience. This concept of competency has been applied in several studies related to assessment in educational contexts (e.g. Krell, 2018; Shavelson, 2013); however, it has been open to scrutiny (Rychen \& Salganik, 2003). In our study, we support the broader notion that competencies are complex, context-specific dispositions that encompass learnable skills and knowledge while empirically examining a component of it.

\section{Scientific Reasoning Competencies}

We suggest that scientific reasoning competencies are a complex construct as well, encompassing the abilities needed for scientific problem solving as well as the capacity to reflect on problem-solving at a meta-level (Krell et al., 2018; Lawson, 2004). Several general cognitive processes have also been suggested as important to reasoning, including, encoding (process of representing information and its context in memory) and retrieval of information, and strategy development (Morris et al., 2012). Knowledge is also intertwined with reasoning as it is important to identify key features of a problem at hand, including content knowledge (knowing that), procedural knowledge (knowing how), and epistemic knowledge (knowing why) (Kind \& Osborne, 2017). In science education literature, content knowledge has been understood as knowledge of domain-specific concepts in science, procedural knowledge as understanding of scientific procedures and strategies, and epistemic knowledge as knowledge about science and how it proceeds (Kind \& Osborne, 2017; Lawson, 2004; Morris et al., 2012). These knowledge types correspond with three possible goals of science education suggested by Canadian science educator, Hodson (2014): learning science (content knowledge), doing science (procedural knowledge), and learning about science (epistemic knowledge). While reasoning in science encompasses a myriad of epistemic, social, and moral dimensions (Samarapungavan, 2018; Schauble, 2018; Allchin, 2013), the focus of this study is only on two common processes associated with science that involve reasoning: investigating and modeling. These processes alone do not represent, or gauge to a great extent, the context-specific cognitive dispositions that are acquired by learning and needed to successfully cope with certain authentic situations in science. While the focus of the study precludes the ethical or affective components of being competent in a domain, we, however, suggest that being competent at investigating and modeling begins to help us understand reasoning in science. 
For the operationalisation of scientific reasoning competencies in this study, a theoretical framework is employed which covers the two sub-competencies conducting scientific investigations and using scientific models (Table 1). The theoretical distinction between these two sub-competencies and associated seven skills of formulating questions, generating hypotheses, planning investigations, analysing data and drawing conclusions, judging the purpose of models, testing models, and changing models was useful for the purposes of systematically developing an instrument used to assess some scientific reasoning competencies in the present study; however, it is recognised that the same processes are used in both investigations and modeling. For example, hypotheses are generated when testing models and evidence is often used to evaluate hypotheses underlying the model (Khan, 2007; Krell et al., 2017).

Scientific reasoning competencies are emphasised in standards documents for science teacher education in many countries around the world (cf. Pedersen et al., 2017). As a result, preservice science teachers are asked to be competent themselves at the same processes stated in curricula for students; for example, working with models, and designing empirical approaches to test hypotheses (Khan, 2018a). It has been put forward that scientific reasoning competencies be emphasised as a part of science teachers' overall professional competency (Mathesius et al., 2016). This study attempts to investigate reasoning competencies for the first time in the context of an intensive science teacher education course and further hypothesise the possible role of a science teacher education program in fostering these scientific reasoning competencies.

\section{Context of the Study: Science Teacher Education in British Columbia, Canada}

\section{Curriculum Development and Competencies in Canadian Curricula}

Curriculum construction is under the purview of provincial ministries in Canada. Canadian science curricula have undergone a recent renewal across the provinces. Like other provinces, the BC Ministry of Education has reconceptualised its curriculum and the concept of competencies has (re-)emerged prominently as part of its curriculum structure of "big ideas", "competencies", and "elaborations." Rather than competencies, historically, "critical thinking skills" were stressed by the BC secondary science curriculum in as early as 1936; however, more recent BC curricula have " $[\mathrm{T}]$ ranscended the idea of critical thinking skills and put forward creative thinking competency" (Sun et al., 2015; p. 16). Indeed, the term "competency" was virtually absent in BC's 2005 K-7 science curriculum, and is now present in the 2016 version of the elementary science-10 curriculum 286 times (Khan, 2018). By 2020, what might be termed as a "competency-driven curriculum" will have fully emerged in the province of BC (https://curriculum.gov. bc.ca/curriculum/overview).

The (re-)introduction of the term competencies in the curriculum has historical vestiges; problematically, "competence" has been associated with a technocratic ideology in an occupational

Table 1 Scientific reasoning competencies and associated sub-competencies of conducting scientific investigations and using scientific models suggested by Hartmann et al. (2015)

Scientific reasoning competencies

\begin{tabular}{lll}
\hline Sub-competencies & Conducting scientific investigations & Using scientific models \\
\hline Skills & Formulating questions & Judging the purpose of models \\
& Generating hypotheses & Testing models \\
& Planning investigations & Changing models \\
& Analysing data and drawing conclusions & \\
\hline
\end{tabular}


culture. Competence and its derivative terms (competencies, performance) in education, furthermore, have been critiqued as being limited in their conceptual reach (Norris, 1991; Spady, 1977). For example, the BC Ministry describes "competency" and "competencies" as a combination of skills, processes, behaviours, proficiencies, and habits of mind (BCMOE, 2019). According to the BC Ministry, students are deemed competent in an area of learning to the extent that they understand and apply knowledge to new contexts. Although the historic, and sometimes unfavourable, association of competency with the assessment of students is not the subject of our paper, we suggest that the resurgence of competencies in Canadian curricula prompt further examination by scholars. We use the term operationally in this study to acknowledge its symbolic adoption in new science education curricula and the need for examining its use critically among stakeholders.

\section{Core Competencies in the BC Curriculum}

BC's redesigned curriculum appears to define competencies at two scales: core competencies develop across the curriculum, and curricular competencies are explicit statements of what is expected at each grade level in each area of learning. The core competencies are throughout all of the subject areas. "[C]ore competencies are sets of intellectual, personal, and social and emotional proficiencies that all students need to develop in order to engage in deep learning and lifelong learning" (BCMOE, 2019). Three domains of core competencies are identified across the curriculum: (1) communication, (2) thinking, (3) personal and social. These competencies are said to come into play when students are engaged in "doing" in any area of learning (BCMOE, 2019). The "doing" includes activities where students use thinking, collaboration, and communication to solve problems, address issues, or make decisions. The ultimate goal is for learners to employ the core competencies every day in school and in life. ${ }^{1}$

The thinking core competency is subdivided into "creative" and "critical" thinking. For critical thinking, it involves making judgments based on reasoning: students consider options; analyse these using specific criteria; and draw conclusions and make judgments. The critical thinking competency encompasses a set of abilities that students use to examine their own thinking, and that of others, about information that they receive through observation, experience, and various forms of communication. The $\mathrm{BC}$ science curriculum is organised with a "know-do-understand" model of learning. The elements in the science curriculum are content ("know"), big ideas ("understand"; emphasising key concepts of the science disciplines), and curricular competencies ("do"). It is suggested that the three elements work together to support competence development and deeper learning in the subject domain (BCMOE, 2019). The curricular competencies in the $\mathrm{BC}$ science curriculum are intended to focus on students' explorations of the subject matter using processes that bear some similarity to those processes in Table 1, such as questioning and predicting, planning and conducting, processing and analysing data and information, evaluating, applying and innovation, and communicating. For example, the Grade 2 BC science 2016 curriculum topic on metamorphic life cycles is: "Students are expected to be able to do the following: questioning and predicting, make simple predictions about familiar objects and events," and the Grade $10 \mathrm{BC}$ science curriculum topic on the universe elaborates: how could you model the formation of the universe (BCMOE, 2019)? The BC Ministry of Education has produced what might be acknowledged as a 'competency-based curriculum' for students and their teachers.

\footnotetext{
${ }^{1}$ The Communication, Thinking, Personal and Social core competencies have been distinguished by the BC Ministry of Education as follows: The communication competency encompasses the set of abilities that students use to impart and exchange information, experiences, and ideas; to explore the world around them; and to understand and effectively engage in the use of digital media. Personal and social competency is the set of abilities that relate to students' identity in the world, both as individuals and as members of their community and society. Personal and social competency encompasses the abilities students need to thrive as individuals, to understand and care about themselves and others, and to find and achieve their purposes in the world. The thinking competency encompasses the knowledge, skills, and processes we associate with intellectual development. It is through their competency as thinkers that students take subjectspecific concepts and content and transform them into a new understanding. Thinking competence includes specific thinking skills as well as habits of mind, and metacognitive awareness (BCMOE, 2019).
} 


\section{Methodology}

The following research questions (RQ) are addressed in this paper:

RQ1. To what extent do secondary preservice science teachers possess scientific reasoning competencies?

RQ2. To what extent does a secondary science teacher education methods course influence preservice science teachers' scientific reasoning competencies?

A previously developed, validated, multiple-choice questionnaire (Krell et al., 2018; Hartmann et al., 2015) was employed to address these questions. This multiple-choice questionnaire assisted the researchers in exploring the extent to which preservice teachers develop their scientific reasoning competencies in an intensive science teacher education course and generating several hypotheses of the role of science teacher education, using the $\mathrm{BC}$ case. Case study can be considered a transparadigmatic heuristic that enables the circumscription of the unit of analysis (VanWynsberghe \& Khan, 2007) and is especially useful in research when focusing on a specific context (intensive science teacher education) where a unit of analysis (scientific reasoning competencies) is being uncovered, circumscribed, or explored more fully (e.g. development in the context of BC programs). To identify a baseline of scientific reasoning competencies and changes after a science teacher education course, a one-group pre- and post-test research design was pursued. This research design involved establishing a baseline measurement for the preservice science teachers and assessing if it changed following a science teacher methods course.

\section{Science Teacher Education Secondary Methods Course}

To investigate preservice science teachers' competencies, participants were sought from a BC secondary teacher education program where the preservice teachers followed a general syllabus for secondary science teacher education. Prior to joining the program, the secondary preservice science teachers were required to have at least one 4-year BSc. degree (or 3-year but an equivalent) in a science area, with no requirement to study education. These degrees usually entail a requirement to do 10 courses or 30 credits of instructional time per year in science, where each credit generally is considered $1 \mathrm{~h}$ per week of instruction. All preservice science teachers must have also completed within this degree, 6 credits of introductory courses in each of chemistry (at least one course with a lab component), mathematics (one or preferably two courses in calculus), physics (at least one course with a lab component), biology, and geology. Furthermore, before enrollment, preservice science teachers must have completed an additional of 6 to 12 credits of first- and second-year-level university science courses and 18 credits of third- and fourth-year-level courses in the selected science. The set of courses for each selected science must have included both lecture and laboratory studies. Preferences were also indicated in terms of applications to the program, for example for a biology teachable subject domain, preference was given to preservice biology teacher applicants who completed courses covering a minimum of 4 of the following areas: ecology, genetics, human physiology, evolutionary biology, invertebrate and vertebrate zoology, non-vascular and vascular plant biology, and microbiology. Specialism courses in these areas must have been completed at the second, third, or fourth year level.

This study was carried out in a general science methods course for all science subjects that were delivered in the first term in the secondary program and was accompanied by a specialism that reinforced the concepts from the methods course. The science methods course was 13 weeks or $39 \mathrm{~h}$ of science methods instruction, in addition to a 2-week "short practicum" that occurred within the course. The science methods course was generally framed as, "Teacher candidates will be introduced to the concept that science teaching is the act of promoting student learning of science through inquiry and are given the opportunity to model, engage in, and reflect upon inquiry teaching in the science classroom." The course objectives combined content (e.g. nature of science, scientific reasoning), pedagogy (e.g. how to foster process skills in science), and 
curriculum (e.g. what are competencies). Course objectives included inquiring into the nature of science and its implications for the teaching of science; articulating and examining their personal philosophy and rationale for teaching science and the role of science in the secondary school curriculum; developing strategies for assessing understanding of science content, scientific reasoning, laboratory processes, and problem solving; acquiring skills in promoting student interest in science and understanding of the role of science in society; recognising the diversity of students' needs, perspectives, and beliefs present in science classrooms, and developing strategies for addressing this diversity in the teaching and learning of science. The course syllabus was comprised of key topics, posed as questions. In this case, a department-wide course syllabus in Table 2 was generally distributed over many years at the university.

An example of a typical course activity was the "Theory Activity Box" otherwise commonly known as a "black box activity" (cf. Krell et al., 2017, in press; Günther et al., 2019). This activity required preservice science teachers to analyse the outcome of pouring a fluid into a black box and observing the quantity and colour of each successive sample. Secondary preservice science teachers would then be commonly asked to reason about why the quantity and colour of the fluid changed for each sample, generate hypotheses about what is happening, make predictions, and eventually, attempt to model the hidden mechanics of the box. The model was then tested against new data. Models were shared in the class, without the box being opened nor the model revealed. Discussions on how science proceeds and how we can reason about a problem regularly ensued.

\section{Participants}

A full cohort of secondary preservice science teachers from a university in British Columbia, consented to participate in this study $(N=56)$. Their mean age was 27 years $(\mathrm{SD}=6.34$; mode $=23)$. Table 3 provides further information about the sample size by major. Data collection was done in their science teacher education secondary methods course, within the Bachelor of Education after degree secondary program.

As mentioned previously, to enroll in the secondary science program, all preservice science teachers had at least one prior degree (usually 4 years of Science or more) as tabulated above.

Pre-post-questionnaire

In order to respond to the research questions, a multiple-choice questionnaire was administered to assess some of the preservice science teachers' scientific reasoning competencies. Scientific reasoning competencies included being competent at skills such as formulating hypotheses regarding models, analysing evidence, and evaluating models (Table 1). As acknowledged, scientific reasoning competencies encompass much more than the aforementioned skills that were tested. The questionnaire was originally developed in Germany in order to monitor the development of scientific reasoning competencies throughout undergraduate and graduate studies at participating universities (Hartmann et al., 2015; Mathesius et al., 2016). The questionnaire included 21 multiple choice items (i.e. three for each skill) related to seven skills identified with aspects of reasoning in science (Table 1). The items were intended to be contextualised in authentic scientific problems. Each item included one attractor (i.e. correct answer) and three distractors (i.e. wrong answers). For the correct identification of the attractor, the preservice teachers need to apply their procedural and epistemic knowledge, for example related to the skill formulating questions, the preservice science teachers needed to know that scientific questions are related to a phenomenon, are empirically testable, intersubjectively comprehensible, unambiguous, principally answerable, and internally and externally consistent (Mathesius et al., 2014).

Previous studies provided different sources of validity evidence that supported the plausibility of the test score interpretations as measures of possible preservice teachers' scientific reasoning competencies. For example, response processes were examined qualitatively (by conducting think-aloud and eye tracking studies), and these studies confirmed that respondents apply procedural and epistemic knowledge to solve 
Table 2 Sample topics taught in a general secondary science education methods course

\begin{tabular}{|c|c|c|}
\hline Date & Topic & Sample lesson activities and questions \\
\hline Sept 10 & $\begin{array}{l}\text { - Course overview } \\
\text { - What is science? } \\
\text { - Views of science learning \& science teaching } \\
\text { - Personal science stories }\end{array}$ & $\begin{array}{l}\text { - Kuhnian science } \\
\text { - Draw a scientist } \\
\text { - Big ideas in science } \\
\text { - What is the nature of science? }\end{array}$ \\
\hline Sept 14 & $\begin{array}{l}\text { - What is science pedagogy? } \\
\text { - What are the elements of science teaching? } \\
\text { - Teaching strategies } \\
\text { - Microteaching }\end{array}$ & $\begin{array}{l}\text { - Videotaping each other teach a topic } \\
\text { - What are some helpful instructional strategies in science? } \\
\text { - How do we plan to promote understanding of science? }\end{array}$ \\
\hline Sept 17 & $\begin{array}{l}\text { - Curriculum, processes of science } \\
\text { - Activity: theory box } \\
\text { - Theme: Nature of Science }\end{array}$ & $\begin{array}{l}\text { - Black box activity } \\
\text { - What is SWT (Science as a Way of Thinking), SBK (Science as a Body of } \\
\text { Knowledge), STS (Science-Technology-Society), and SWI (Science as a Way } \\
\text { of Investigating)? }\end{array}$ \\
\hline Sept 21 & $\begin{array}{l}\text { - How do children learn science? } \\
\text { - Constructivism } \\
\text { Undemo (Intro) }\end{array}$ & $\begin{array}{l}\text { - Children's conceptions } \\
\text { - Conceptual change } \\
\text { - Demonstrations that are interactive vs. didactic } \\
\text { - How do we learn? What is constructivism? } \\
\text { - What is critical thinking? }\end{array}$ \\
\hline Sept 24 & $\begin{array}{l}\text { - Introduction to scientific methods } \\
\text { - Curriculum, processes of science } \\
\text { - Coke challenge }\end{array}$ & $\begin{array}{l}\text { - Which can of cola floats experiment and the scientific method. } \\
\text { - The curriculum and processes of inquiry } \\
\text { - What is the secondary science curriculum? What happened to PLOs (prescribed } \\
\text { learning outcomes) and IRPs (integrated resource package or the curriculum } \\
\text { package)? What are competencies? }\end{array}$ \\
\hline Sept 28 & $\begin{array}{l}\text { - Lesson planning / curriculum } \\
\text { - Bloom's taxonomy } \\
\text { - Inquiry/ questioning }\end{array}$ & $\begin{array}{l}\text {-What goes into lesson planning and unit planning? How do we promote and } \\
\text { assess science understanding through questioning? }\end{array}$ \\
\hline Oct 1 & - Guest speaker & - Teacher from schools or organizations \\
\hline Oct 5 & - UnDemo & $\begin{array}{l}\text { - The Undemo is cast as an non-traditional demonstration. It is designed to be } \\
\text { interactive. }\end{array}$ \\
\hline Oct 8 & No class & \\
\hline Oct 12 & • Unit planning/ UnDemo & \\
\hline Oct 15 & - Concept mapping/ UnDemo & - What are some ways students can represent their knowledge? \\
\hline Oct 19 & - Learning science in context & $\begin{array}{l}\text { - How should we teach in the inclusive science classroom? What is First } \\
\text { Indigenous Knowledge and are they the result of Other Ways of Knowing? }\end{array}$ \\
\hline Oct 22 & - Safety & - Lab Safety Manual \\
\hline Oct 26 & - Labs \& cognitive overload & $\begin{array}{l}\text { - Why is "hands-on" good? Is it OK to lecture? } \\
\text { - What is the value of note-taking? } \\
\text { - Cognitive overload }\end{array}$ \\
\hline Oct 29 & $\begin{array}{l}\text { - Assessment } \\
\text { - Roles of assessment types } \\
\text { - Rubrics }\end{array}$ & $\begin{array}{l}\text { - How do we know what students have understood and learned? In what ways can } \\
\text { we gather evidence for, of, and as learning? }\end{array}$ \\
\hline Nov 2 & - Assessment, test designs & - What are some ways students can represent their knowledge? \\
\hline Nov 5 & $\begin{array}{l}\text { - Field studies } \\
\text { - Scenario-based assessments }\end{array}$ & $\begin{array}{l}\text { - What is experiential learning? } \\
\text { - What are process skills and how can we evaluate them? }\end{array}$ \\
\hline Nov 9 & - Vernier probes & - Labs with probe technology \\
\hline Nov 12 & No class & \\
\hline Nov 16 & Practicum - No class & \\
\hline Nov 19 & Practicum - No class & \\
\hline Nov 23 & Practicum - No class & \\
\hline Nov 26 & - Translations & - Teaching science for children with special needs in reading and writing \\
\hline Nov 30 & $\begin{array}{l}\text { - Science, Technology, Society, and Environment } \\
\text { (STSE) Education - TECH session } \\
\text { - Computer modeling (SageModeler) }\end{array}$ & - How to teach science with technology \\
\hline Dec 3 & - Unit plan and lesson plan assignment & \\
\hline Dec 7 & $\begin{array}{l}\text { - Aluminum Boat Challenge } \\
\text { - Teaching philosophy } \\
\text { - Final class }\end{array}$ & \\
\hline
\end{tabular}

the multiple-choice problems (e.g. Mathesius et al., 2018). Furthermore, statistical analyses revealed good psychometric properties and a one-dimensional data structure representing one overall latent dimension scientific reasoning competencies (Hartmann et al., 2015). As some authors critique a lack of validity 
Table 3 Sample size and demographics of BC preservice teacher participants

\begin{tabular}{lll}
\hline Primary major & Biology & 30 \\
& Chemistry & 11 \\
& Physics & 8 \\
& Biomedicine, Earth Sciences, Mathematics & 1 (each) \\
& n/a & 4 \\
& B.Sc. & 45 \\
Previous degrees* & M.Sc. & 8 \\
& PhD & 2 \\
& B.Ed., B.Eng. & 1 (each) \\
& n/a & 9 \\
Number of previous degrees & One & 44 \\
& More than one & 7 \\
nex & Female & 5 \\
& Male & 32 \\
& Other & 24 \\
\hline
\end{tabular}

*There are $n=7$ preservice teachers with more than one previous degree

evidence for instruments to assess scientific reasoning competencies (e.g. Osborne, 2013), the consideration of this comprehensive validity evidence can be seen as a distinguishing quality criterion of the instrument. A sample investigation type question from the questionnaire is shown in Fig. 1 below.

The questionnaire was initially translated into English and Spanish in order to enable international comparisons. Since the English version was developed outside of Canada (based on a sample of $N=105$ Australian pre-service science teachers; Krell et al., 2018), it was first given to Canadian researchers from education, science, and the social sciences from British Columbia ("critical experts"; $N=5$ ), who were asked to provide feedback on the questionnaire to identify the level of clarity of the task in English. Based on the experts' feedback, several adjustments to English sentence construction, semantics, spelling, and grammar were made to adapt the questionnaire to the Canadian context. The questionnaire was administered to the preservice science teachers in their methods courses in a university in BC, at the end and at the beginning of the semester (pre-post-assessment). All procedures performed in this study involving preservice teacher participants were in accordance with the ethical standards of the university and with the 1964 Helsinki declaration and its later amendments or comparable ethical standards. There were 56 pre-service teachers who completed the pre- and post-questionnaire. Therefore, each question had a maximum number of $N=112$ responses in general. Missing responses did occur in a few of the single items.

\section{Data Analysis}

Data were analysed within the frameworks of classical test theory (CTT) and item response theory (IRT; Bond \& Fox, 2001; Field, 2009). Next to obtaining classical mean scores $(M)$, person abilities $\left(\theta_{\mathrm{s}}\right)$ and item difficulties $\left(\beta_{\mathrm{i}}\right)$ at the latent level were estimated on the one-dimensional One-Parameter Logistic Model (1PLM) for dichotomous items ("Rasch Model") using the software ACER Conquest (Wu et al., 2007). Weighted maximum likelihood estimates (WLE) were used as point estimates for $\theta_{\mathrm{s}}$ (cf. Wu et al., 2007), that is, as indicators for the preservice science teachers' scientific reasoning competencies. IRT has widely been applied in science education research (e.g. Krell et al., 2018; Neumann et al., 2011). One major advantage of IRT models, such as the 1PLM, is the estimation of derived parameters for person abilities $\left(\theta_{\mathrm{s}}\right)$ and item difficulties $\left(\beta_{\mathrm{i}}\right)$ on a ratio scale - as opposed to raw scores within CTT (Boone et al., 2014; Neumann et al., 2011). Furthermore, person abilities can be estimated even in the case of missing responses to single items. Different fit-indices have been proposed to evaluate the appropriateness of the estimated parameters $\theta_{\mathrm{s}}$ and $\beta_{\mathrm{i}}$ and to ensure methodological accuracy (Bond \& Fox, 2001; Boone et al., 2014). One 


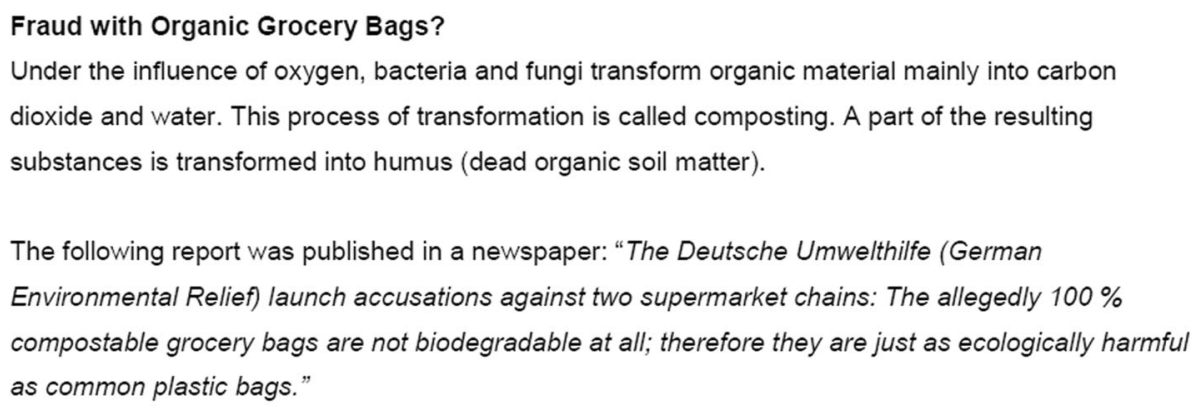

A team of experts has been asked to conduct a scientific investigation into how compostable are these organic grocery bags really?

\section{Which scientific question might underlie this investigation?}

Tick one of the boxes below.

What impact do the biological decomposition products from the organic grocery bags have on the environment?

What biological decomposition products are formed in the process of composting the organic grocery bags?

What materials comprise the organic grocery bags?

Are there any substances formed in the process of composting the organic grocery bags that cannot further be decomposed?

Fig. 1 Investigation-type question from the questionnaire used in this study (Krell et al., 2018). The full questionnaire is available upon request to the second author.

established fit-index is the sum of the squared standardised residuals (MNSQ), which has an expected value of 1 with acceptable values ranging from 0.8 to 1.2 (Bond \& Fox, 2001). ACER Conquest computes a weighted and an unweighted MNSQ. Because the unweighted MNSQ is more sensitive to outliers than the weighted MNSQ, both statistics should be considered. In addition, $t$-standardised fit statistics based on the MNSQ are provided, which should range from -2 to 2 (Wu et al., 2007).

To evaluate to what extent the preservice science teachers possessed an adequate level of scientific reasoning competencies (RQ 1$)$, the relation of person ability $\left(\theta_{\mathrm{s}}\right)$ and item difficulty $\left(\beta_{\mathrm{i}}\right)$ within the 1PLM was employed (cf. Bond \& Fox, 2001):

$$
P\left(X_{i s}\right)=\frac{\exp \left(\theta_{s}-\beta_{i}\right)}{1+\exp \left(\theta_{s}-\beta_{i}\right)}
$$

As a consequence of the 1PLM's equation, $\theta_{\mathrm{s}}$ and $\beta_{\mathrm{i}}$ are estimated on a one common logit-scale and can be illustrated accordingly in so-called Wright Maps (Bond \& Fox, 2001). Further, a person with $\theta_{\mathrm{s}}=\beta_{\mathrm{i}}$ has a $50 \%$ probability to answer the respective item correctly; if $\theta_{\mathrm{s}}>\beta_{\mathrm{i}}$, this probability is more than $50 \%$, and if $\theta_{\mathrm{s}}<\beta_{\mathrm{i}}$, this probability is less than $50 \%$ (Bond \& Fox, 2001). In this study, the sample's mean ability $\left(M_{\mathrm{WLE}}\right)$ was centred at $M_{\mathrm{WLE}}=0$ to allow for a free estimation of the items' difficulties ("constraints = 
cases"; Wu et al., 2007); however, this constraint does not affect the relation between person ability and item difficulty described above.

Three subgroups of the Canadian sample were distinguished for each skill associated with scientific reasoning, the two sub-competencies, and for scientific reasoning competencies overall (as per Table 1). Respondents with WLE $>M_{\beta}+1 \mathrm{SD}_{\beta}$ were defined as having advanced competencies, whereas respondents with WLE $<M_{\beta}-10_{\beta}$ were labelled as having basic competencies. Respondents who had somewhere between advanced and basic competencies (i.e. WLE $=M_{\beta} \pm 1 \mathrm{SD}_{\beta}$ ) were referred to as transitional (cf. Krell et al., 2018). For discussing RQ2, the effect of teacher education on the preservice science teachers' test scores (i.e. WLE) was estimated statistically ( $t$ tests, ANOVA).

\section{Methodological Limitations}

There are several limitations acknowledged at the outset of the study. Conceptually, the researchers adopted a definition of competencies as a disposition and complex system of skills that is established in science education research (Klieme et al., 2008; Krell, 2018), but competency might be considered even more broadly (Rychen \& Salganik, 2003). Furthermore, a multiple-choice questionnaire was used to assess scientific reasoning competencies, for which various evidence are available to support the test score interpretation as measures of preservice teachers' scientific reasoning competencies (e.g. Hartmann et al., 2015; Mathesius et al., 2018). Compared to "authentic" scientific problems, however, paper-based assessments necessarily lack complexity (Shavelson, 2013). The researchers, nonetheless, embarked upon the study as a measure of potential scientific reasoning competencies that could assist in generating hypotheses about the role of teacher education and the facets that might help to develop these competencies.

\section{Results}

This study analysed to what extent secondary preservice science teachers possess scientific reasoning competencies (RQ 1), using BC teacher education as an idealised case of an intensive science education period. To perform the analysis, the researchers employed a questionnaire (or test) at the beginning and end of a science teacher education course in this discrete and intensive program of study. This design permitted the researchers to generate hypotheses about to what extent the course influence secondary preservice science teachers' scientific reasoning competencies (RQ 2).

In examining preservice science teachers' competencies in general at scientific reasoning, the researchers analysed pre- and post-questionnaire data at first taken together. The total response sample for each item was thus $N=n_{\text {pre }}+n_{\text {post }}$ or $N=112$. Table 4 below illustrates the proportion of correct answers (i.e. raw data) and the estimated item difficulty parameter (i.e. $\beta_{\mathrm{i}}$ ) for the items related to the seven skills of scientific reasoning (mentioned previously in Table 1). Table 4 shows, for example, that in general, a substantial majority of items related to planning investigations were answered correctly among preservice science teachers (about 74\% correct answers), whereas the items related to generating hypotheses were the most challenging to answer (about 36\%). Over half of the preservice science teachers responded correctly on items related to the larger categories of both conducting scientific investigations and using scientific models. In terms of modeling, more items involving testing models were correctly responded to than other items related to modeling. Overall, on both questionnaires, the items were answered correctly by just over $50 \%$ of the preservice science teachers.

To help further assess what this finding means in terms of difficulty, the researchers reviewed the item difficulty parameters of the questions estimated within the one-dimensional 1PLM. In the 1PLM, the EAP/ $\mathrm{PV}$ reliability is rel. $=0.48$, which is in the accepted range of previous studies (e.g. rel. $=0.44$ in Mathesius et al., 2016; rel. $=0.55$ in Krell et al., 2018). The item separation reliability is rel. $=0.95$. MNSQ- and 
Table 4 Proportion of correct answers (i.e. $1.0=100 \%$ correct answers) and estimated item difficulty parameters $\beta_{\mathrm{i}}$

\begin{tabular}{lllr}
\hline Scientific reasoning related skills and competencies & Item numbers & $\begin{array}{l}\text { Proportion of correct answers } \\
(M \pm \mathrm{SD})\end{array}$ & $\begin{array}{l}\beta_{\mathrm{i}} \\
(M \pm \mathrm{SD})\end{array}$ \\
\hline Formulating questions & $1-3$ & $0.42 \pm 0.29$ & $0.37 \pm 0.52$ \\
Generating hypotheses & $4-6$ & $0.36 \pm 0.28$ & $0.63 \pm 0.60$ \\
Planning investigations & $7-9$ & $0.74 \pm 0.22$ & $-1.28 \pm 1.38$ \\
Analysing data and drawing conclusions & $10-12$ & $0.60 \pm 0.28$ & $-0.66 \pm 1.62$ \\
Conducting scientific investigations & $1-12$ & $0.53 \pm 0.14$ & $-0.24 \pm 1.26$ \\
Judging the purpose of models & $13-15$ & $0.45 \pm 0.27$ & $0.22 \pm 1.10$ \\
Testing models & $16-18$ & $0.51 \pm 0.32$ & $0.00 \pm 0.27$ \\
Changing models & $19-21$ & $0.48 \pm 0.29$ & $0.09 \pm 0.57$ \\
Using scientific models & $13-21$ & $0.48 \pm 0.20$ & $0.10 \pm 0.64$ \\
Scientific reasoning (i.e. overall) & $1-21$ & $0.50 \pm 0.14$ & $-0.09 \pm 1.03$ \\
\hline
\end{tabular}

The two sub-competencies assessed are highlighted in italics.

corresponding $t$ values indicate a good fit between data and model (unweighted: $0.82 \leq \mathrm{MNSQ} \leq 1.10,|t| \leq$ 1.40; weighted: $0.93 \leq \mathrm{MNSQ} \leq 1.07,|t| \leq 1.60$ ).

Figure 2 below depicts the person ability and item difficulty parameters within the Wright Map. The mean score of the estimated person abilities is centred at $M_{\mathrm{WLE}}=0$ ("constraints = cases"; see above); however, the relation between person ability (i.e. WLE) and item difficulty (i.e. $\beta_{\mathrm{i}}$ ) reveals some interesting patterns. In the Wright Map, rather easy items are located at the bottom (i.e. low item difficulty parameters $\beta_{\mathrm{i}}$ ) and harder items at the top (i.e. higher $\beta_{\mathrm{i}}$ ). For example, Fig. 2 reveals that the skills formulating questions and generating hypotheses were comparatively more difficult (i.e. high item difficulty parameters

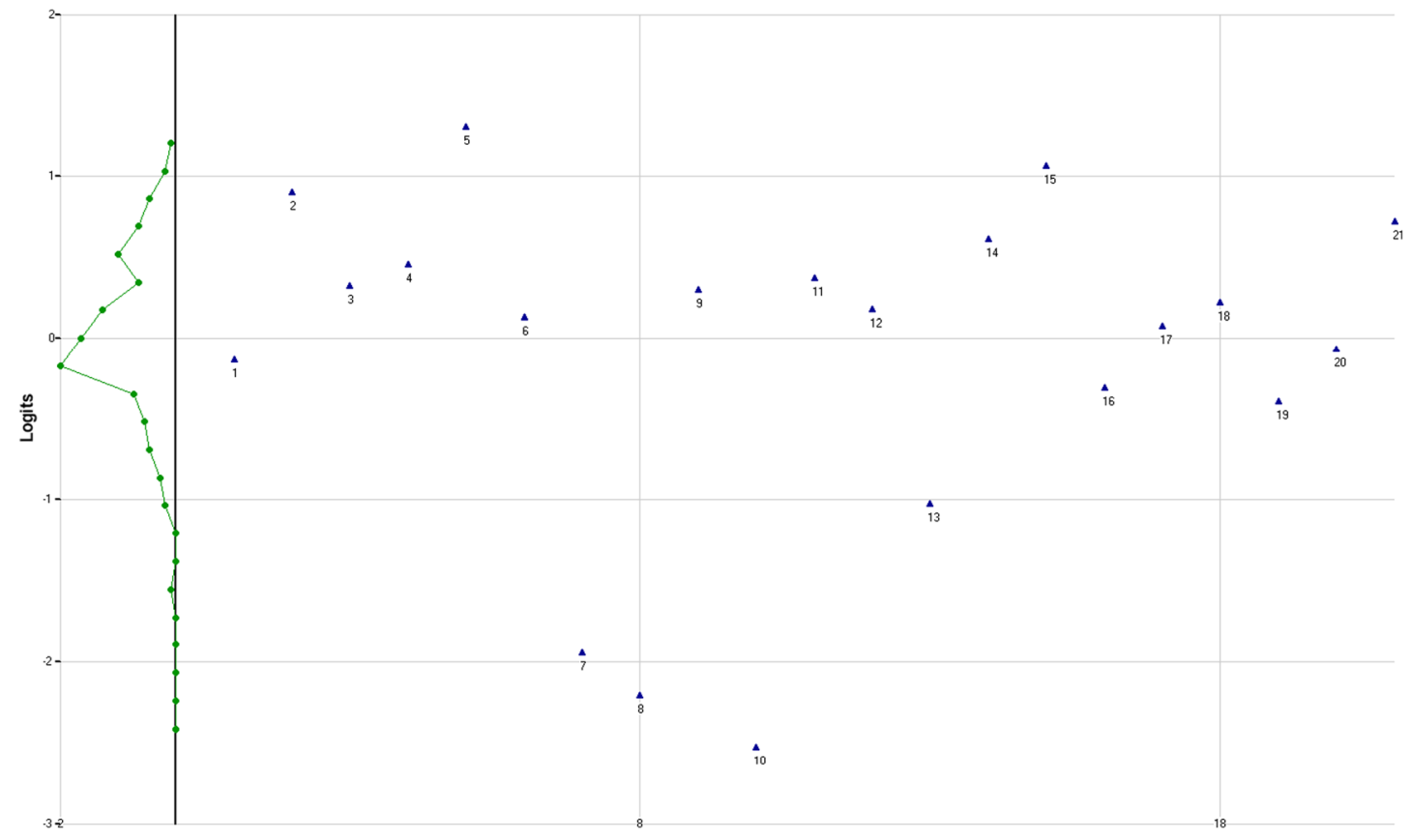

Fig. 2 Wright map illustrating case distribution and item difficulty within one-logit scale; triangles, items; connected circles, case distribution. Item numbers match with Table 4; 1-3 formulating questions, 4-6 generating hypotheses, 7-9 planning investigations, 10-12 analysing data and drawing conclusions, 13-15 judging the purpose of models, 16-18 testing models, and 19-21: changing models 
of 0.37 and 0.63 respectively; Table 4), than planning investigations, the easiest category of scientific reasoning competencies (i.e. low item difficulty parameters of -1.28 ; Table 4). It should be noted that for planning investigations, the relative difficulty of the items within this sub-competency varied considerably more (cf. standard deviations in Table 4), with planning investigations item 9 being far more difficult than planning investigations items 7 and 8 (Fig. 2).

The researchers also utilised a definition for basic, transitional, and advanced competencies described in the "Data Analysis" section, in order to distinguish between different subgroups within the sample, each with a specific level of competency in scientific reasoning. Table 5 below introduces the total number of responses from preservice teacher on both tests who were considered to be within a particular subgroup or level of competency, as well as the number of preservice teacher responses within these specific subgroups from the pre- and post-questionnaires combined (referred to as the total sample).

Based on the above procedures, it was concluded that the majority of the participating preservice science teachers had transitional level competencies for both investigating and modeling. As shown in Table 5, a noteworthy proportion of preservice science teachers were advanced at planning investigations and testing models. Also, more preservice teachers performed at a basic level for the skill of generating hypotheses than other skills. Interestingly, no preservice teachers performed at a basic level in planning investigations nor analysing data and drawing conclusions. In examining responses associated with modeling more closely, more responses were deemed to be at advanced or transitional levels for judging the purpose of models than testing models or changing models. Collectively, almost all preservice science teachers performed solidly at a transitional level, which is true for the total sample as well as for the pre- and the post-tests individually.

In exploring pre- and post-course differences, on average and based on the estimated WLE, there was no significant difference found between the pre- $\left(M_{\mathrm{WLE}}=0.04, \mathrm{SD}=0.62\right)$ and the post-test score $\left(M_{\mathrm{WLE}}=-\right.$

Table 5 Number of preservice science teacher responses within the three subgroups in each skill, the two sub-competencies, and scientific reasoning overall

\begin{tabular}{|c|c|c|c|c|}
\hline Scientific reasoning related skills & & Basic & Transitional & Advanced \\
\hline \multirow[t]{2}{*}{ Formulating questions } & Total sample & 46 & 57 & 9 \\
\hline & Pre/post & $21 / 25$ & $31 / 26$ & $4 / 5$ \\
\hline \multirow[t]{2}{*}{ Generating hypotheses } & Total sample & 57 & 50 & 5 \\
\hline & Pre/post & $26 / 31$ & $27 / 23$ & $3 / 2$ \\
\hline \multirow[t]{2}{*}{ Planning investigations } & Total sample & 0 & 64 & 48 \\
\hline & Pre/post & $0 / 0$ & $33 / 31$ & $23 / 25$ \\
\hline \multirow[t]{2}{*}{ Analysing data and drawing conclusions } & Total sample & 0 & 103 & 9 \\
\hline & Pre/post & $0 / 0$ & $52 / 51$ & $4 / 5$ \\
\hline \multirow[t]{2}{*}{ Conducting scientific investigations } & Total sample & 1 & 106 & 5 \\
\hline & Pre/post & $0 / 1$ & $53 / 53$ & $3 / 2$ \\
\hline \multirow[t]{2}{*}{ Judging the purpose of models } & Total sample & 10 & 100 & 2 \\
\hline & Pre/post & $3 / 7$ & $53 / 47$ & $0 / 2$ \\
\hline \multirow[t]{2}{*}{ Testing models } & Total sample & 45 & 22 & 45 \\
\hline & Pre/post & $20 / 25$ & $13 / 9$ & $23 / 22$ \\
\hline \multirow[t]{2}{*}{ Changing models } & Total sample & 26 & 67 & 19 \\
\hline & Pre/post & $12 / 14$ & $34 / 33$ & $10 / 9$ \\
\hline \multirow[t]{2}{*}{ Using scientific models } & Total sample & 25 & 69 & 18 \\
\hline & Pre/post & $11 / 14$ & $36 / 33$ & $9 / 9$ \\
\hline \multirow[t]{2}{*}{ Scientific reasoning (i.e. overall) } & Total sample & 3 & 100 & 9 \\
\hline & Pre/post & $1 / 2$ & $51 / 49$ & $4 / 5$ \\
\hline
\end{tabular}

The two sub-competencies assessed are highlighted in italics 
$0.05, \mathrm{SD}=0.71, p=0.470)$. In the pre-test, however the preservice science teachers with a major in biology $(n=30)$ achieved significantly higher test scores $\left(M_{\mathrm{WLE}}=0.23, \mathrm{SD}=0.46\right)$ than those with a non-biology major $\left(n=26, M_{\mathrm{WLE}}=-0.18, \mathrm{SD}=0.72, p=0.015, d=0.68\right.$; medium effect size). This difference is only marginally significant and with a lower effect size measure $(d)$ in the post-test $(p=0.065 ; d=0.50$; medium effect size). This might suggest that the course contributed to diminish differences in scientific reasoning competencies between preservice teachers with and without biology as a major. Interestingly, it was also found that those preservice teachers with more than one previous degree $(n=0.7)$ performed significantly better in the post-test $\left(M_{\mathrm{WLE}}=0.41, \mathrm{SD}=0.73\right)$ than their colleagues with only one previous degree $\left(M_{\mathrm{WLE}}=-0.13, \mathrm{SD}=0.69, p=0.064, d=0.74\right.$; medium effect size $)$. There was no significant difference between these groups in the pre-test $(p=0.613)$.

The latter finding hints to a group-specific influence of the science teacher education methods course on the preservice science teachers' scientific reasoning competencies. In line with this assumption, a two-way ANOVA with the sum of previous degrees (dichotomous variable with $0=$ one, $1=$ two or more) and the time of assessment $(0=$ pre-test, $1=$ post-test $)$ was performed and suggests an interaction effect sum of previous degrees $\times$ time of assessment. Due to the small sample size, however, this interaction was not found to be statistically significant (Table 6). A simple effects analysis (cf. Field, 2009) reveals a marginally significant difference between the test scores of both groups for the post-test $(p=0.05)$ that suggests that, in terms of scientific reasoning competencies, those preservice teachers with more than one previous degree might benefit more from the course than their colleagues with only one previous degree.

The interaction graph (Fig. 3) above suggests that for both the pre- and the post-tests, the preservice teachers with more than one previous degree outperform their colleagues with only one previous degree. Additionally, the test scores of those with more than one previous degree increased from pre to post (but not statistically significant), and a non-significant decrease could be identified for those with one previous degree (Fig. 3).

\section{Discussion}

Related to RQ1, the overall findings suggest that the BC preservice science teachers mainly possess scientific reasoning competencies on what could be termed a transitional level. As shown in Table 5, however, two exceptions are the skills of planning investigations and testing models, where about $40 \%$ of the sample were identified as having advanced competencies. Comparatively, for the other investigative dimensions of scientific reasoning, formulating questions and generating hypotheses, less than $10 \%$ of the total sample were in the advanced subgroup with the vast majority being solidly at the transitional level or transitional to basic. For the modeling dimensions, few preservice teachers (about 20\%) were identified as having transitional competencies in testing out a given model (Table 5), with the majority of preservice teachers being at either advanced or a basic level of competency related to this skill. Krell and Krüger (2016) show in a study with in-service biology teachers that those teachers with a better understanding of testing

Table 6 Two-way ANOVA with the sum of previous degrees (degrees) and the time of assessment (time) as independent variables $\left(R^{2}=0.04\right)$

\begin{tabular}{lllllll}
\hline & $S S$ & df & MS & $F$ & $p$ & Partial $\eta^{2}$ \\
\hline Time & 0.06 & 1 & 0.06 & 0.13 & 0.72 & 0.00 \\
Degrees & 1.35 & 1 & 1.35 & 3.03 & 0.09 & 0.03 \\
Time * degrees & 0.49 & 1 & 0.49 & 1.10 & 0.29 & 0.01 \\
Error & 43.37 & 97 & 0.45 & & & \\
Total & 45.37 & 100 & & & & \\
\hline
\end{tabular}




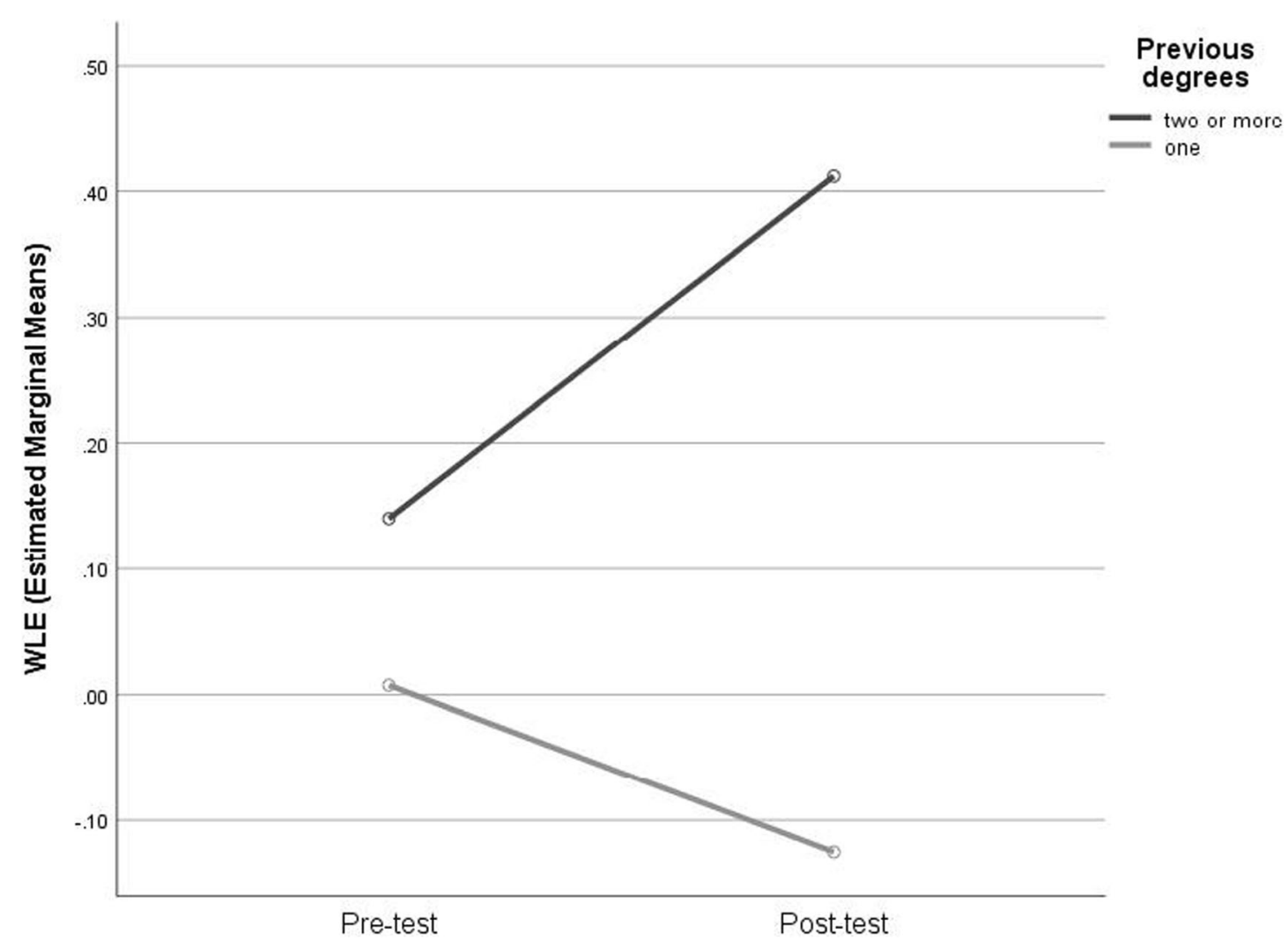

Fig. 3 Interaction graph sum of previous degrees $\times$ time of assessment

models also more intensively conduct sophisticated model-based teaching activities. In terms of judging the purpose of models and changing models, preservice science teachers were performing predominantly at advanced or transitional levels of competency. Independent of these two differences in investigatory and modeling skills, the overall findings suggest that $\mathrm{BC}$ preservice science teachers possess a satisfactory (i.e. transitional) overall level of scientific reasoning competencies, yet might be challenged to address certain aspects involving modeling in the newly created, competency-based science curriculum (BCMOE, 2019). This curriculum emphasises students' competencies at developing inquiry questions and generating hypotheses as well as skills associated with testing and changing models in science. In an international context, it should be duly noted that, in a similar study from Australia ( $\mathrm{M}=0.45, N=105$ preservice science teachers enrolled in a Master of Teaching; Krell et al., 2018), the proportion of correct answers in the present Canadian sample was slightly higher $(\mathrm{M}=0.50$; Table 4$)$. This finding suggests that the need for developing reasoning competencies in science teacher education supersedes this case and is of potentially international import to science teacher education programs.

Related to RQ2, the findings reveal that there is no significant influence of a science education methods course on preservice science teachers' scientific reasoning competencies. This finding contradicts other science education research that suggest that science teacher education courses that reflect upon scientific reasoning positively impact preservice science teachers' scientific reasoning competencies within a concurrent teacher education program (e.g. Hartmann et al., 2015). Others assert, however, that it is a complex and time-consuming task to foster preservice science teachers' scientific reasoning competencies (e.g. Kenyon et al., 2011). This research, on the other hand, might explain why an intensive after-degree teacher education program within one semester of science education does not appear, at the outset, to be sufficient to reach this goal. Beyond this, there are several other alternative hypotheses that could explain this result. For 
example, another hypothesis is that the questionnaire measured something other than scientific reasoning competencies. This alternative hypothesis does not seem initially probable as the questionnaire has been used internationally and was evaluated in various studies providing evidence for the valid interpretation of the test scores (e.g. Krell et al., 2018; Hartmann et al., 2015; Mathesius et al., 2016). Preservice teachers also did not take the questionnaire home.

Secondly, as with pre-post-test designs, it should be acknowledged that there are other viable probes that might further reveal what the preservice teachers did learn, such as observable evidence of reasoning during microteaching activities, scenario-based qualitative assessments, or analyses of philosophy statements about the nature of science and modeling (Khan, 2018). Thirdly, while the purpose of the study was not to examine particular activities within the curriculum in relationship to the outcomes on the questionnaires, the study does generate several hypotheses about the types of activities employed in science teacher education that might impact teachers' scientific reasoning. Activities like the black box activity (Krell et al., 2017, in press; Günther et al., 2019), in addition to those mentioned in other studies, such as contemporary and historical case studies (Allchin et al., 2014), explicit instruction (Khishfe, 2014), and authentic and structured research partnerships (Sadler et al., 2010), have been proposed as supporting the development of future teachers' learning of science and scientific reasoning. The teacher education curriculum plays a role in the development of these competencies.

The present research points to several other factors that could conceivably contribute to the development of scientific reasoning competencies in teacher education. For example, although there was no statistically significant interaction effect sum of previous degrees $\times$ time of assessment in the two-way ANOVA (Table 6), there was a medium and significant difference in the post-test between preservice teachers with more than one and only one previous degree. This finding suggests a possible influence of background knowledge on the development of scientific reasoning competencies within science teacher education. It is plausible, for instance, that preservice teachers with more than one previous degree are better able to relate teacher education activities like the black box activity to already known scientific contexts they have encountered and, thus, might benefit more from this activity than their peers with one degree might. This study puts forward that there might be an additional benefit to having at least one degree as a pre-requisite for science teacher education. The need exists for ample future research that examines and compares the development of preservice science teachers' scientific reasoning competencies within different teacher education systems.

\section{Concluding Remarks}

Internationally, competency-based curricula support the idea that teachers foster competencies of their students. Science teacher education can play a role in supporting the development of preservice teachers' own science competencies in these areas. Orienting science teacher education to support the development of preservice teachers' competencies at reasoning is a laudable goal and one that is enhanced when cognitive processes are paired with necessary epistemic, social, and moral dimensions of problem-solving associated with scientific problems. Researchers investigated the effect of an intensive after-degree teacher education program on the development of preservice science teachers' scientific reasoning competencies. This setting departs from research on a longer, concurrent program of teacher education (Hartmann et al., 2015). The study here uniquely reveals that the science methods course was effective in fostering scientific reasoning competencies of those preservice teachers with more than one previous degree in science. This finding further suggests that research on competency development be considered for both longitudinal and intensive measures and that substantial background knowledge supports competence development.

For teacher education, it can be recommended that science teacher educators consider a range of highimpact course activities to foster teachers' own reasoning in science alongside how to teach students how to reason (cf. Khan, 2018). Several examples of how to enhance student competencies in educational 
environments have been suggested in research, including providing complex, authentic problems, that are not manageable by applying only single skills or automatised procedures (Max, 1999; Shavelson, 2013). In terms of science teacher education, competence development might be supported by providing a sequence of contextualisation (i.e. problem solving in an authentic scientific context), decontextualisation (i.e. explicit reflection), and recontextualisation (i.e. problem solving in another or an analogous authentic context). Such a strategy for science teacher education is supported by data from a longitudinal study on the development of preservice science teachers' scientific reasoning competencies that further suggest that explicit reflections about scientific reasoning (i.e. learning about science; Hodson, 2014) contributes more to the development of scientific reasoning competencies, than only doing science without reflecting about it (Hartmann et al., 2015; Mathesius et al., 2016). Similarly, it has recently been demonstrated that a problem-based teacher education program, including modeling activities (e.g. black box activity) and explicit reflections of these activities, successfully fostered preservice biology teachers modeling competencies (Günther et al., 2019) and in other studies of science preservice teachers (Khan, 2018). Kenyon et al. (2011) also suggest five design principles to successfully foster teachers' epistemic knowledge and their pedagogical content knowledge related to scientific modeling: (1) Teachers should engage in the full range of scientific modeling, including (2) developing models for explanations and predictions (3) and the revision of models based on evidence; (4) teachers need to develop epistemic knowledge, subject matter knowledge, and pedagogical content knowledge related to scientific modeling; and finally, (5) modeling activities should be considered in multiple content areas. The author's (Khan, 2018b) research also suggests that science teacher educators consider ways for preservice science teachers to engage in similar activities on practicum, the point when preservice science teachers are especially challenged to foster modeling and investigatory competencies with students. Clearly, our overarching research findings suggest that part of the consideration of designing a science teacher education curriculum should include preservice science teacher's background knowledge entering the program and the benefits of a prior degree or degrees in science in terms of reasoning. Finally, this study supports the potential for intensive science teacher education programs to foster teacher competency with more high-impact activities. It holds potential significance as well to those internationally who have developed or enacted competency-oriented science curricula, as science teachers will need to be competent at reasoning in order to assist their future students to solve problems in science.

Acknowledgements The authors would like to acknowledge the assistance of Alexis Gonzalez in data collection.

\section{Compliance with Ethical Standards}

All procedures performed in this study involving preservice teacher participants were in accordance with the ethical standards of the university and with the 1964 Helsinki declaration and its later amendments or comparable ethical standards.

Conflict of Interest The authors declare that they have no conflict of interest.

Open Access This article is distributed under the terms of the Creative Commons Attribution 4.0 International License (http:// creativecommons.org/licenses/by/4.0/), which permits unrestricted use, distribution, and reproduction in any medium, provided you give appropriate credit to the original author(s) and the source, provide a link to the Creative Commons license, and indicate if changes were made.

\section{References}

Alberta Program of Study. (2016). Retrieved June 25, from: https://education.alberta.ca/science-10-12/

Allchin, D. (2013). Teaching the nature of science: Perspectives and resources. Saint Paul, MN: SHiPS Education Press.

Allchin, D., Andersen, H., \& Nielsen, K. (2014). Complementary approaches to teaching Nature of Science: Integrating student inquiry, historical cases, and contemporary cases in classroom practice. Science Education, 98, 461-486. 
Bond, T., \& Fox, C. (2001). Applying the Rasch model. Mahwah, NJ: Erlbaum.

Boone, W., Staver, J., \& Yale, M. (2014). Applying rasch measurement in science education research. Dordrecht: Springer.

British Columbia Ministry of Education (BCMOE). (2019-2011; 2005). Curriculum redesign. Retrieved from the BCMOE website: https://curriculum.gov.bc.ca/rethinking-curriculum

Field, A. (2009). Discovering statistics using SPSS. Los Angeles, CA: Sage.

Ford, M. (2008). "Grasp of practice" as a reasoning resource for inquiry and nature of science understanding. Science \& Education, 17(2\&3), 147-177.

Günther, S., Fleige, J., Upmeier zu Belzen, A., \& Krüger, D. (2019). Using the case method to foster preservice biology teachers' content knowledge and pedagogical content knowledge related to models and modeling. Journal of Science Teacher Education, 11, 1-23. doi:https://doi.org/10.1080/1046560X.2018.1560208

Hartmann, S., Upmeier zu Belzen, A., Krüger, D., \& Pant, H. (2015). Scientific reasoning in higher education. Zeitschrift für Psychologie, 223, 47-53. doi:https://doi.org/10.1027/2151-2604/a000199

Hodson, D. (2011). Looking to the future: Building a curriculum for social activism. Rotterdam/Taipei: Sense Publishers.

Hodson, D. (2014). Learning science, learning about science, doing science: Different goals demand different learning methods. International Journal of Science Education, 36(15), 2534-2553. doi:https://doi.org/10.1080 /09500693.2014.899722

Kelly, G. J., Carlsen, W., \& Cunningham, C. (1993). Science education in sociocultural context. Science Education, 77(2), $207-$ 22.

Kenyon, L., Davis, E., \& Hug, B. (2011). Design approaches to support preservice teachers in scientific modeling. Journal of Science Teacher Education, 22(1), 1-21. doi:https://doi.org/10.1007/s10972-010-9225-9 .

Khan, S. (2007). Model-based inquiries in chemistry. Science Education, 91(6), 877-905.

Khan, S. (2018a, September). Crossing continents: An examination of comparative science curricula. "The aims and purposes of science education: The Canadian context". European Conference on Educational Research (ECER) Annual Conference, Bolzano, Italy.

Khan, S. (2018b). Preservice teacher education activities and their impact on model-based teaching. Annual Meeting of the National Association for Research in Science Teaching (NARST), Atlanta, GA.

Khishfe, R. (2014). Explicit nature of science and argumentation instruction in the context of socioscientific issues: An effect on student learning and transfer. International Journal of Science Education, 36(6), 974-1016.

Kind, P., \& Osborne, J. (2017). Styles of scientific reasoning: A cultural rationale for science education? Science Education, 101(1), 8-31. doi:https://doi.org/10.1002/sce.21251 .

Klieme, E., Hartig, J., \& Rauch, D. (2008). The concept of competence in educational contexts. In J. Hartig, E. Klieme, \& D. Leutner (Eds.), Assessment of competencies in educational contexts (pp. 3-22). Göttingen: Hogrefe.

KMK [Sekretariat der Ständigen Konferenz der Kultusminister der Länder in der BRD] (Ed.). (2005). Bildungsstandards im Fach Biologie für den Mittleren Schulabschluss [Biology education standards for the Mittlere Schulabschluss]. München \& Neuwied: Wolters Kluwer.

Krell, M. (2018). Schwierigkeitserzeugende Aufgabenmerkmale bei Multiple-Choice-Aufgaben zur Experimentierkompetenz im Biologieunterricht: Eine Replikationsstudie [Difficulty generating task characteristics of multiple-choice-tasks to assess experimental competencies]. Zeitschrift für Didaktik der Naturwissenschaften, 24, 1-15. doi:10.1007/s40573017-0069-0

Krell, M., \& Krüger, D. (2016). Testing models: A key aspect to promote teaching-activities related to models and modelling in biology lessons? Journal of Biological Education, 50, 160-173. doi: 10.1080/00219266.2015.1028570

Krell, M., Walzer, C., Hergert, S., \& Krüger, D. (2017). Development and application of a category system to describe preservice science teachers' activities in the process of scientific modelling. Research in Science Education. doi: 10.1007/ s11165-017-9657-8

Krell, M., Redman, C., Mathesius, S., Krüger, D., \& van Driel, J. (2018). Assessing pre-service science teachers' scientific reasoning competencies. Research in Science Education. doi:10.1007/s11165-018-9780-1

Krell, M., \& Hergert, S. (in press). The blackbox approach: Analyzing modeling strategies. In A. Upmeier zu Belzen, D. Krüger, \& J. van Driel (Eds.), Towards a competence-based view on models and modeling in science education. Springer.

Lawson, A. (2004). The nature and development of scientific reasoning: A synthetic view. International Journal of Science and Mathematics Education, 2, 307-338. doi:https://doi.org/10.1007/s10763-004-3224-2 .

Lubchenco, J. (2017). Environmental science in a post-truth world. Frontiers in Ecology and the Environment, 15(3). doi: https://doi.org/10.1002/fee.1454

Mathesius, S., Upmeier zu Belzen, A., \& Krüger, D. (2014). Kompetenzen von Biologiestudierenden im Bereich der naturwissenschaftlichen Erkenntnisgewinnung: Entwicklung eines Testinstruments [Competencies of biology students in the field of scientific inquiry: Development of a testing instrument]. Erkenntnisweg Biologiedidaktik, 13, 73-88.

Mathesius, S., Hartmann, S., Upmeier zu Belzen, A., \& Krüger, D. (2016). Scientific reasoning as an aspect of preservice biology teacher education. In T. Tal \& A. Yarden (Eds.), The future of biology education research. Proceedings of the 10th conference of European Researchers in Didactics of Biology (ERIDOB) (pp. 93-110).

Mathesius, S., Upmeier zu Belzen, A. \& Krüger, D. (2018). Eyetracking als Methode zur Untersuchung von Lösungsprozessen bei Multiple-Choice-Aufgaben zum wissenschaftlichen Denken [Eye-tracking as a method to investigate response 
processes in mutliple-choice items on scientific reasoning]. In: M. Hammann \& M. Lindner (Hrsg.), Lehr-und Lernforschung in der Biologiedidaktik, Band 8 (pp. 225-244). Innsbruck: Studienverlag.

Max, C. (1999). Entwicklung von Kompetenz: Ein neues Paradigma für das Lernen in Schule und Arbeitswelt. Frankfurt am Main: Peter Lang.

Morris, B., Croker, S., Masnick, A., \& Zimmerman, C. (2012). The emergence of scientific reasoning. In H. Kloos, B. Morris, \& J. Amaral (Eds.), Current topics in children's learning and cognition (pp. 61-82). InTech.

Nehring, A., Nowak, K., zu Belzen, Annette Upmeier, \& Tiemann, R. (2015). Predicting students' skills in the context of scientific inquiry with cognitive, motivational, and sociodemographic variables. International Journal of Science Education, 37, 1343-1363.

Neumann, I., Neumann, K., \& Nehm, R. H. (2011). Evaluating instrument quality in science education: Rasch-based analyses of a Nature of Science test. International Journal of Science Education, 33, 1373-1405.

NGSS Lead States (Ed.). (2013). Next Generation Science Standards: For states, by states. Washington, DC: The National Academies Press.

Norris, N. (1991). The trouble with competence. Cambridge Journal of Education, 21(3),331-341.

OECD. (2010). The high cost of low educational performance: The long-run economic impact of improving PISA outcomes (PISA). Paris. Retrieved from https://www.oecd.org/pisa/44417824.pdf

Osborne, J. (2013). The 21st century challenge for science education: Assessing scientific reasoning. Thinking Skills and Creativity, 10, 265-279. doi:https://doi.org/10.1016/j.tsc.2013.07.006

Pedersen, J. E., Isozaki, T., \& Hirano, T. (Eds.). (2017). Model science teacher preparation programs: An international comparison of what works. Charlotte, NC: Information Age.

Quebec Education Program (2001). Retrieved June 25, 2019, from: http://www.education.gouv.qc.ca/en/teachers/quebeceducation-program/

Rychen, D., \& Salganik, L. (2003). A holistic model of competence. In D. Rychen \& L. Salganik (Eds.), Key competencies for a successful life and a well-functioning society (pp. 41-62). Cambridge, Mass.: Hogrefe \& Huber.

Sadler, T. D., Burgin, S., McKinney, L., \& Ponjuan, L. (2010). Learning science through research apprenticeships: A critical review of the literature. Journal of Research in Science Teaching, 47(3), 235-256.

Samarapungavan, A. (2018). Construing scientific evidence: The role of disciplinary knowledge in reasoning with and about evidence in scientific practice. In Scientific Reasoning and Argumentation (pp. 66-86). Routledge.

Schauble, L. (2018). In the eye of the beholder: Domain-General and domain-specific reasoning in science. In Scientific Reasoning and Argumentation (pp. 21-43). Routledge.

Shavelson, R. (2013). On an approach to testing and modeling competence. Educational Psychologist, 48(2), 73-86. doi: https://doi.org/10.1080/00461520.2013.779483.

Spady, W. G. (1977). Competency based education: A bandwagon in search of a definition. Educational Researcher, 6(1), 9-14.

Sun, C., Raptis, H., \& Weaver, A.J. (2015). Crowding the curriculum” Changes to Grades 9 and 10 Science in BC-1914-2014. Canadian Journal of Education / Revue canadienne de l'éducation, 1-31.

VanWynsberghe, R., \& Khan, S. (2007). Redefining case study. International Journal of Qualitative Methods, 6(2), 80-94.

Weinert, F. (2001). Concept of competence: A conceptual clarification. In D. Rychen \& L. Salganik (Eds.), Defining and selecting key competencies (pp. 45-65). Kirkland, WA: Hogrefe.

Wu, M. L., Adams, R., Wilson, M., \& Haldane, S. (2007). ACER ConQuest. Camberwell, Vic: ACER Press.

Publisher's Note Springer Nature remains neutral with regard to jurisdictional claims in published maps and institutional affiliations. 